\title{
Attitudes to smoking and smoking habit among the staff of a hospital
}

\author{
P D O DAVIES, K RAJAN \\ From Llandough Hospital, Penarth, South Glamorgan
}

ABSTRACT A survey of the smoking habits and attitudes towards smoking of all staff working in a ir teaching hospital with a specialist thoracic department has been carried out. Six hundred and sixty $\underset{\sim}{\omega}$ three $(\mathbf{7 0 \%})$ of the 949 members of staff returned a voluntary self completed questionnaire. Completion rates were highest among medical, administrative, and clerical staff, and lowest among domestic and catering staff. Of the 663 responders, $136(23 \%)$ admitted to being current smokers and $z$ $135(19 \%)$ to being ex-smokers. The great majority of responders (81-94\%, depending on area of work) believed that more areas of the hospital should be entirely smoking free. Most responders, $\vec{\bullet}$ however, believed that some accommodation should be made available to staff (70\%), patients 0 $(52 \%)$, or visitors $(59 \%)$ who wished to smoke. About a quarter of smokers expressed interest in joining a group to help them give up smoking.

\section{Introduction}

Over 10 years have passed since the Department of Health and Social Security issued a circular entitled Non-Smoking in Health Premises.' Little progress appears to have been made in implementing this policy, perhaps because of a reluctance to adopt a change that might cause controversy.

To comply with the policy of the South Glamorgan Health Authority, Llandough Hospital recently declared itself to be a "non-smoking" hospital. Llandough Hospital, which contains the specialist department of thoracic medicine, has 450 beds and, with two other hospitals, comprises the University Hospital of Wales. Although many surveys have been conducted on smoking habits of doctors, nurses, and other health professionals, ${ }^{2-4}$ there is little information regarding the attitudes of other hospital staff. ${ }^{5}$ We therefore undertook a survey of the smoking habits and attitudes of all paid staff in Llandough Hospital to determine their attitudes towards the implementation of a non-smoking hospital policy as well as estimating their own habits.

Address for correspondence: Dr P D O Davies, South Liverpool Chest Clinic, Sefton General Hospital, Liverpool L15 2HE. (Reprints will not be available.)

Accepted 13 February 1989

\section{Methods}

The names of all currently employed staff of the hospital on 1 March 1987 were obtained.

Staff employed less than half time at Llandough Hospital were excluded from the survey. The survey questionnaire was designed to be self completed. The information requested included sex, age, department in which employed, and whether the respondent was a non-smoker or ex-smoker, and if a smoker the quantity of cigarettes smoked. Respondents were asked their opinion about which parts of the hospital should be declared to be a non-smoking area. They were also asked their opinion about whether staff, patients, and visitors should have access to smoking and nonsmoking facilities throughout 24 hours. Further ques- of tions specifically asked whether they thought smoking $N$ and non-smoking areas should be present in the $N$ cafeterias and dining room. Finally, smokers were $\omega$ asked whether they would wish to join a support group to help them to give up smoking. Each questionnaire $\stackrel{\varrho}{=}$ included a unique survey code number so that non- $\mathbb{D}$ respondents could be identified and traced and a reminder sent to them.

On "No-smoking Day," 11 March 1987, question- $\stackrel{\circ}{\overparen{D}}$

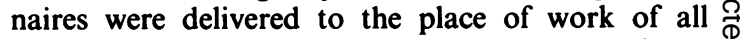
hospital staff with an accompanying explanatory letter $\stackrel{ }{\varrho}$ and addressed personally in a sealed envelope. Staff were asked to complete the questionnaire and return it 
to the central posting box in the general office of the hospital or directly back to the coordinators.

One month after the questionnaires had been sent, a copy of the questionnaire and explanatory letter were sent personally to all who had not responded. Forms returned more than two months after the initial survey were excluded from the analysis.

\section{Results}

The results of the survey are shown in tables 1-3. A total of 949 staff employed at Llandough Hospital were identified, of whom $663(70 \%)$ completed and returned the questionnaire. Table 1 shows the response rate from the eight departments in the hospital and the numbers of non-smokers, current smokers, and ex-smokers.

Female hospital staff numbered 727, of whom 499 $(69 \%)$ responded. Of these, $112(22 \%)$ were current smokers and $82(16 \%)$ ex-smokers. Of the 222 male staff, $160(73 \%)$ responded. Of these, $24(15 \%)$ were current smokers and 53(33\%) ex-smokers. Among the responders a higher proportion of men than women were ex-smokers $\left(\chi^{2}=14.36, p<0.01\right)$. There was no difference between the sexes for lifelong non-smoking $\left(\chi^{2}=4 \cdot 8, \mathrm{p}>0 \cdot 1\right)$. Most responders believed that wards and offices $(93 \%)$, halls and corridors $(88 \%)$, toilets and changing areas $(81 \%)$, and laboratories $(94 \%)$ should be non-smoking areas (table 2). Most of them $(81 \%)$ also thought that smoking should be forbidden in the cafeteria, though $2 \%$ of doctors, $11 \%$ of nurses, $28 \%$ of domestic staff, and $31 \%$ of works staff disagreed with this policy. Altogether $20 \%$ of respondents thought that there should be some tables for smoking in the restaurant. The proportion varied from $16 \%$ of doctors and administrative and clerical staff and $33 \%$ of catering and portering staff, to $66 \%$ of domestic staff.

Nearly all respondents (87-95\%) believed that all hospital users should have access to smoke free rest rooms at all times (table 3). A slightly smaller number of respondents thought that there should be access to smoking rest rooms throughout the $\mathbf{2 4}$ hours for staff $(70 \%)$, visitors $(59 \%)$, and patients $(52 \%)$ (table 3$)$. When answers to this question were analysed by smoking habit, 247 of $390(63 \%)$ non-smokers believed that staff should have access to smoking rest rooms, $215(55 \%)$ believed that visitors should have access, but less than half $(184,47 \%)$ believed that patients should have access.

Table 1 Response rate and smoking habit by department

\begin{tabular}{|c|c|c|c|c|c|c|c|c|c|c|}
\hline \multirow[b]{2}{*}{ Department } & \multicolumn{3}{|c|}{ No of staff } & \multirow{2}{*}{$\begin{array}{l}\text { Response } \\
\text { rate }(\%)\end{array}$} & \multicolumn{3}{|c|}{ Smoking number } & \multicolumn{3}{|l|}{$\%$} \\
\hline & Total & $M$ & $F$ & & $N$ & $P$ & $E x$ & $N$ & $\boldsymbol{P}$ & $E x$ \\
\hline $\begin{array}{l}\text { Nursing* } \\
\text { Doctors } \\
\text { Administrative, clerical } \\
\text { Scientific } \\
\text { Domestic } \\
\text { Catering } \\
\text { Portering } \\
\text { Works } \\
\text { Total }\end{array}$ & $\begin{array}{r}361 \\
94 \\
110 \\
163 \\
106 \\
60 \\
34 \\
21 \\
949\end{array}$ & $\begin{array}{r}10 \\
78 \\
9 \\
65 \\
0 \\
5 \\
34 \\
21 \\
222\end{array}$ & $\begin{array}{r}351 \\
16 \\
101 \\
98 \\
106 \\
55 \\
0 \\
0 \\
727\end{array}$ & $\begin{array}{l}75 \\
72 \\
82 \\
77 \\
47 \\
28 \\
74 \\
76 \\
70\end{array}$ & $\begin{array}{r}165 \\
48 \\
54 \\
81 \\
16 \\
8 \\
11 \\
5 \\
388\end{array}$ & $\begin{array}{r}56 \\
2 \\
16 \\
14 \\
28 \\
6 \\
11 \\
3 \\
136\end{array}$ & $\begin{array}{r}47 \\
18 \\
20 \\
30 \\
6 \\
3 \\
3 \\
8 \\
135\end{array}$ & $\begin{array}{l}61 \\
71 \\
61 \\
65 \\
32 \\
47 \\
44 \\
31 \\
59\end{array}$ & $\begin{array}{r}21 \\
3 \\
18 \\
11 \\
57 \\
35 \\
44 \\
19 \\
23\end{array}$ & $\begin{array}{l}17 \\
26 \\
26 \\
23 \\
12 \\
18 \\
12 \\
50 \\
19\end{array}$ \\
\hline
\end{tabular}

$\mathrm{N}$-non-smoker; P-present smoker; Ex-ex-smoker.

${ }^{*}$ Four nurses did not complete question on smoking habit.

Table 2 Non-smoking areas

\begin{tabular}{|c|c|c|c|c|c|c|c|c|}
\hline \multirow[b]{2}{*}{ Department } & \multirow[b]{2}{*}{$\begin{array}{l}\text { No of } \\
\text { replies }\end{array}$} & \multicolumn{3}{|c|}{ More non-smoking areas needed (\% agreeing) } & \multicolumn{4}{|c|}{ Smoking should be forbidden (\% agreeing) } \\
\hline & & $\begin{array}{l}\text { For } \\
\text { staff }\end{array}$ & $\begin{array}{l}\text { For } \\
\text { patients }\end{array}$ & $\begin{array}{l}\text { For } \\
\text { visitors }\end{array}$ & $\begin{array}{l}\text { Wards, } \\
\text { offices }\end{array}$ & $\begin{array}{l}\text { Halls, } \\
\text { corridors }\end{array}$ & $\begin{array}{l}\text { Toilets, } \\
\text { changing } \\
\text { areas }\end{array}$ & Laboratories \\
\hline $\begin{array}{l}\text { Nursing } \\
\text { Doctors } \\
\text { Administrative, clerical } \\
\text { Scientific } \\
\text { Domestic } \\
\text { Catering } \\
\text { Portering } \\
\text { Works } \\
\text { Total } \\
\text { Don't know* }\end{array}$ & $\begin{array}{r}272 \\
68 \\
90 \\
125 \\
50 \\
17 \\
25 \\
16 \\
663\end{array}$ & $\begin{array}{l}78 \\
87 \\
68 \\
90 \\
60 \\
60 \\
84 \\
81 \\
76 \\
7\end{array}$ & $\begin{array}{l}78 \\
90 \\
69 \\
92 \\
58 \\
65 \\
80 \\
63 \\
78 \\
7\end{array}$ & $\begin{array}{l}76 \\
88 \\
74 \\
90 \\
54 \\
59 \\
76 \\
63 \\
77 \\
7\end{array}$ & $\begin{array}{r}92 \\
99 \\
94 \\
98 \\
86 \\
94 \\
96 \\
88 \\
93 \\
3\end{array}$ & $\begin{array}{r}91 \\
96 \\
86 \\
91 \\
62 \\
88 \\
80 \\
75 \\
88 \\
6\end{array}$ & $\begin{array}{r}84 \\
96 \\
85 \\
88 \\
50 \\
76 \\
40 \\
50 \\
81 \\
8\end{array}$ & $\begin{array}{r}93 \\
99 \\
94 \\
98 \\
88 \\
100 \\
92 \\
88 \\
94 \\
4\end{array}$ \\
\hline
\end{tabular}

*The remainder disagreed. 
Table 3 Attitudes to access to smoking rest rooms

\begin{tabular}{|c|c|c|c|c|c|c|c|}
\hline \multirow[b]{2}{*}{ Department } & \multirow[b]{2}{*}{$\begin{array}{l}\text { No of } \\
\text { replies }\end{array}$} & \multicolumn{3}{|c|}{ Want $24 h$ access to non-smoking rest rooms (\%) } & \multicolumn{3}{|c|}{ Want $24 h$ access to smoking rest rooms (\% } \\
\hline & & $\begin{array}{l}\text { For } \\
\text { staff }\end{array}$ & $\begin{array}{l}\text { For } \\
\text { patients }\end{array}$ & $\begin{array}{l}\text { For } \\
\text { visitors }\end{array}$ & $\begin{array}{l}\text { For } \\
\text { staff }\end{array}$ & $\begin{array}{l}\text { For } \\
\text { patients }\end{array}$ & $\begin{array}{l}\text { For } \\
\text { visitors }\end{array}$ \\
\hline $\begin{array}{l}\text { Nursing } \\
\text { Doctors } \\
\text { Administrative, clerical } \\
\text { Scientific } \\
\text { Domestic } \\
\text { Catering } \\
\text { Portering } \\
\text { Works } \\
\text { Total } \\
\text { Don't know* }\end{array}$ & $\begin{array}{r}272 \\
68 \\
90 \\
125 \\
50 \\
17 \\
25 \\
16 \\
663\end{array}$ & $\begin{array}{l}96 \\
93 \\
97 \\
96 \\
92 \\
88 \\
96 \\
94 \\
95 \\
3\end{array}$ & $\begin{array}{r}90 \\
91 \\
83 \\
94 \\
76 \\
65 \\
84 \\
81 \\
87 \\
4\end{array}$ & $\begin{array}{r}90 \\
90 \\
86 \\
93 \\
76 \\
88 \\
92 \\
88 \\
88 \\
3\end{array}$ & $\begin{array}{r}74 \\
40 \\
77 \\
72 \\
72 \\
59 \\
88 \\
81 \\
70 \\
3\end{array}$ & $\begin{array}{r}57 \\
21 \\
53 \\
59 \\
50 \\
41 \\
60 \\
50 \\
52 \\
3\end{array}$ & $\begin{array}{r}62 \\
29 \\
61 \\
63 \\
60 \\
41 \\
80 \\
69 \\
59 \\
3\end{array}$ \\
\hline
\end{tabular}

*The remainder disagreed.

Nineteen responders $(3 \%)$ did not believe that breathing other people's cigarette smoke is bad for health. Of 136 current smokers who responded, 36 $(26 \%)$ thought that they would like to join a special group to help them give up smoking.

\section{Discussion}

The overall response rate of $70 \%$ from all staff of the hospital is similar to the response in other surveys ${ }^{5}$ and reflects the desire of nearly all staff to cooperate in this survey.

The response rates were highest from the administrative and clerical, nursing, and medical staff, and lowest from the catering and domestic staff. The departments with the highest proportion of smokers among responders were generally those with the lowest response rates. Previous studies have also shown a lower response rate among smokers. ${ }^{6}$ Probably nearly all non-responders are smokers. If all non-responders were smokers $47 \%$ of the hospital staff would be smokers. A slightly higher proportion of male $(73 \%)$ than of female staff $(69 \%)$ responded. Of the responders, rather more men than women $(52 \%)$ were lifelong non-smokers $(62 \%)$ (not statistically significant). A very much larger proportion of men claimed to be ex-smokers $(33 \%)$ than women $(16 \% ; p<0.01)$, emphasising the observation that the message about the dangers of smoking is getting across to more men than women.

There was a large measure of agreement among all groups of responders that more non-smoking areas should be provided in the hospital for staff, patients, and visitors (table 3). The departments with the highest proportion of smokers among the responders-namely, domestic and catering staff-in general saw less need than the others for further non-smoking areas. Most responders (88-94\%) believed that smoking should be forbidden in wards, offices, halls, corridors, toilets, changing rooms, laboratories, and the cafeteria, though fewer respondents from the domestic, works, and portering departments shared ${ }_{-}^{-}$ this opinion. Again, these figures are broadly similar to those from other surveys. ${ }^{57}$

Perhaps the single most important finding of the $\overrightarrow{\mathscr{Q}}$ survey is that most responders, whether smokers or 0 non-smokers, thought that staff and visitors should have access to smoking rest rooms. Most considered that access to such rest rooms should be available to staff $(70 \%)$, visitors $(59 \%)$, and patients $(52 \%)$. Even among the lifelong non-smokers, $47 \%$ believed that $\stackrel{D}{\mathcal{Q}}$ patients should have access to a smoking rest room. $\vec{P}$ Medical staff stood out against the trend, only $21 \% \frac{\text { 의 }}{3}$ believing that patients should have access to smoking rooms.

A small proportion of people working in hospital, all of whom were smokers, were still unaware of the dangers of passive smoking. In this climate of opinion it might be difficult to exclude smoking completely from hospital premises. The policy most likely to be 3 . enforceable and satisfactory to the greatest number of $\mathcal{O}$ hospital staff would be to ban smoking from all parts of the hospital except for three designated places, 을 where staff, patients, and visitors respectively would be permitted to smoke. This would avoid the need foro furtive smoking among the addicted, with its attendant safety dangers. Unless such measures are suppor- $\Omega$ ted and enforced by all hospital staff, the tendency is to $N$ have a "smoking policy" by default, with people స్ట

smoking in forbidden areas. that they would like to join a special group to help them give up smoking suggests that setting up such a group within the hospital may be worthwhile.

A survey of health authorities in the United Kingdom suggests that many have not implemented a ${ }_{\odot}$ "no smoking" policy. ${ }^{8}$ The increased awareness of the $\vec{\nabla}$ dangers of smoking by hospital staff that occurred as $a_{\bar{\sigma}}$ result of a smoking survey was associated with a decrease in smoking among health workers elsewhere. ${ }^{9}$ 
Surveys of smoking habits in hospital may help to reduce the incidence of smoking among hospital staff. $^{10}$ It is a matter of concern that, despite the overwhelming evidence that smoking is a major cause of death and illness, up to half of the work force in a specialist thoracic hospital in the United Kingdom may be current smokers. ${ }^{\prime \prime}$

We would like to thank all staff of Llandough Hospital for their enthusiastic cooperation. We also thank the medical personnel department, Temple of Peace and Health, Cardiff, and the department of nursing, the personnel department, and the works department of Llandough Hospital for providing the names of all staff members in the hospital. Finally, we thank Heather Thomas and Nicola Moon for typing the manuscript.

\section{References}

1 Department of Health and Social Security, Health Services Management. Non-smoking in health premises. London: Department of Health and Social Security, (HC (77)3). 1977.
2 Fletcher C, Doll R. A survey of doctor's attitudes to smoking. Br J Prev Soc Med 1969;23:145-53.

3 Doll R, Peto R. Mortality in relation to smoking: 20 years' observations on male British doctors. $\mathrm{Br}$ Med J 1976;ii:1525-36.

4 Jones MC. The prevalence of smoking among nurses of the Forth Valley Health Board area. Health Bulletin 1985;43:240-4.

5 Chilvers Clair, Chamberlain Joselyn, Fox Hazel, Calnan M, Bosc V. Smoking and other health-related behaviour among staff of a general hospital, a specialist cancer hospital and a medical research centre. Commun Med 1987;9:1-14.

6 Burgess AM, Tierney JT. Bias due to nonresponse in a mail survey of Rhode Island physician's smoking habits-1968. $N$ Engl J Med 1970;282:908.

7 Ball K, Stevenson A. Hospital action on smoking. $\mathrm{Br}$ Med J 1979;ii:777-8.

8 Batten L. The NHS as an agent of change: creating a smoke-free environment in the hospital. Health Trends 1988;20:70-5.

9 Andrews JL. Reducing smoking in the hospital. An effective model program. Chest 1983;84:206-9.

10 Catford JC, Nutbeam D. Smoking in hospitals. Lancet 1983;ii:94-6.

11 Ferguson P, Small WP. Further study of the smoking habits of hospital nurses. Health Bulletin 1985;43:13-8. 